\title{
Applying Design Thinking as a Method for Teaching Packaging Design
}

\author{
Chao-Ming Yang ${ }^{1}$ \\ ${ }^{1}$ Department of Visual Communication Design, Ming Chi University of Technology, New Taipei City, Taiwan \\ Correspondence: Chao-Ming Yang, 84 Gungjuan Rd., Taishan Dist., New Taipei City 24301, Taiwan. Tel: \\ 886-2-2908-9899.
}

Received: May 17, 2018

Accepted: June 6, $2018 \quad$ Online Published: June 18, 2018

doi:10.5539/jel.v7n5p52

URL: https://doi.org/10.5539/jel.v7n5p52

\begin{abstract}
Design thinking is a human-centered creative method that can be used to seek innovative solutions for life and social topics. Moreover, design thinking can enable developing innovative ideas that can satisfy consumer needs. A packaging design course is a professional course that combines material application, design aesthetics, and branding. It is also a comprehensive science course that emphasizes developing students' creative thinking and the ability to use practical technologies. This study applied an experimental teaching method to introduce design thinking in a packaging design course. The aim was to guide students to identify problems from the perspectives of product packaging, brand image, spatial structure, and marketing. Students were expected to be able to reconsider the meaning and importance of packaging design and thus enhance their structural creativity, visual aesthetics, and design thinking, in addition to improving their rational analysis and design problem-solving abilities.
\end{abstract}

Keywords: design thinking, packaging design, design education, visual communication design

\section{Introduction}

Design thinking has been highly appreciated by scholars and used by businesses and organizations to solve social and commercial problems and to cope with increasing complexity of society, as well as satisfy consumers' inner needs (Dunne \& Martin, 2006). A review of research in the past 10 years revealed that increasing numbers of scholars have strongly promoted using the design thinking approach to address the increasingly complex social and environmental trends and propose more innovative problem-solving methods (Lugmayr, Stockleben, \& Zou, 2014). Design thinking is a human-centered problem-solving approach (Melles, Howard, \& Thompson-Whiteside, 2012); solutions derived using this approach afford considerable possibilities of innovation (Brown \& Wyatt, 2010). The main difference between design thinking and traditional analytical thinking is that design thinking is a creative thinking approach that tends toward emotional analysis, whereas analytical thinking is based on rational analysis (Razzouk \& Shute, 2012). The design thinking approach enables designers to identify actual customer needs and propose rational, artistic, and innovative ideas to address such needs (Lugmay, 2011). In recent years, numerous education strategies have introduced design thinking into classes in order to stimulate students' conception of innovative ideas to resolve existing problem or expected problems (Scheer, Noweski, \& Meinel, 2012).

Packaging design involves both visual design and product design and is related to brand visual identity, container structure, and product functionality. In addition, packaging design requires high levels of creativity and professional skills (DuPuis \& Silva, 2011; Orth \& Malkewitz, 2008). In Asia, teaching methods for packaging design mostly focus on internal factors - namely visual design teaching - including product rendering, design methods, and presentation and visual imagery styles; teaching methods focusing on external factors associated with packaging design, such as the social background of packaging, use instruction, and consumer groups, are relatively few (Wang, 2016). Furthermore, packaging design in Taiwan involves several problems such as lack of creativity in shape designs, lack of professional packaging designers, lack of cooperative marketing strategies, and lack of manufacturing technology (Hsu, 2002). Therefore, the traditional teaching model for packaging design is limited to teaching students to emphasize artistic effects. This model can no longer meet the demand of the new economic era. Accordingly, the objective of this study was to introduce design thinking in the teaching of packaging design, with the aim of guiding students to solve problems from the perspective of product 
packaging, brand image, spatial structure, and marketing. We hope that this packaging design teaching method can help students reconsider the meaning of packaging design and increase their structural creativity, visual aesthetic, and design thinking abilities in product packaging as well as enhance their capabilities to rationally analyze and solve design problems.

\section{Literature Review}

\subsection{Design Thinking}

In recent years, design thinking has been increasingly applied in industry and education. Tim Brown (2008), chief executive officer of the design firm IDEO, defined design thinking as "a discipline that uses the designer's sensibility and methods to match people's needs with what is technologically feasible and what a viable business strategy can convert into customer value and market opportunity" The design thinking approach was developed by Stanford University in the 1980s. Specifically, the Stanford d.school applies this approach to train students to solve actual problems related to products, services, and consumers or to develop innovative solutions that fit consumers' needs across industries from the perspective of human needs (Lugmayr, Stockleben et al., 2014). Design thinking is suitable for training cross-border teams; such teams can focus on deriving an understanding of the relationship between problems and users, gaining inspiration and conception for solutions (ideation), and implementing the solutions to solve the problems (Johansson-Sköldberg, Woodilla, \& Çetinkaya, 2013). Currently, educators condense the inspiration process of design thinking into five steps (Figure 1): empathy, define, ideate, prototype, and test (Scheer et al., 2012).

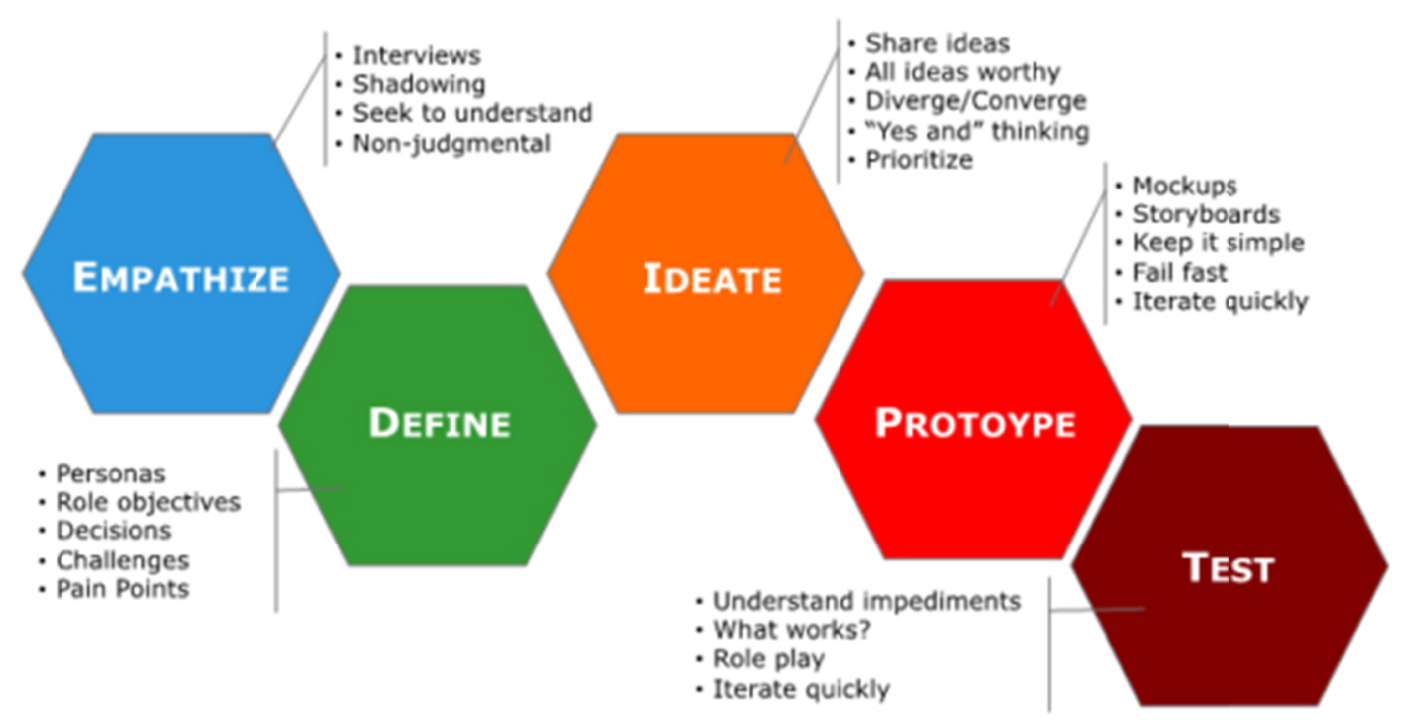

Figure 1. Five-steps design thinking process proposed by Stanford University

Source: www.enterpriseirregulars.com/125085/what-is-design-thinking

In many fields, knowledge is generated and accumulated through systematic activities, but design thinking entails problem-solving strategies through group brainstorming activities (Razzouk \& Shute, 2012). Johansson-Sköldberg et al. (2013) proposed that design thinking is a method that combines theory and practice and emphasizes solving complex problems and producing more innovative designs through teamwork. Dunne and Martin (2006) reported that design thinking entails integrating the ideas of all team members during the process of collaboration and finally providing the optimal solution from the team. This innovative method can be applied not only in product development but also in organizational management and in addressing social issues. However, in design thinking training, students must be taught how to apply observation strategies to implement solutions that approximate human needs (Rauth et al., 2010). Lindberg, Meinel, and Wagner (2011) also proposed that design thinking training should focus on prompting students to conceive innovative ideas or seek solutions for major problems. In this process of creative inspiration, each individual may propose new ideas or integrate several innovative ideas to form an innovative design plan. Tschimmel (2012) stated that design thinking is a "double-diamond" design process in which team members collaborate to understand problems, conduct group observations of the problems, brainstorm on design ideas, and develop a product prototype (Discover $\rightarrow$ Define $\rightarrow$ Develop $\rightarrow$ Deliver). This process enables all team members to focus on the same problem 
simultaneously and thus propose innovative ideas that align with human needs (Figure 2).

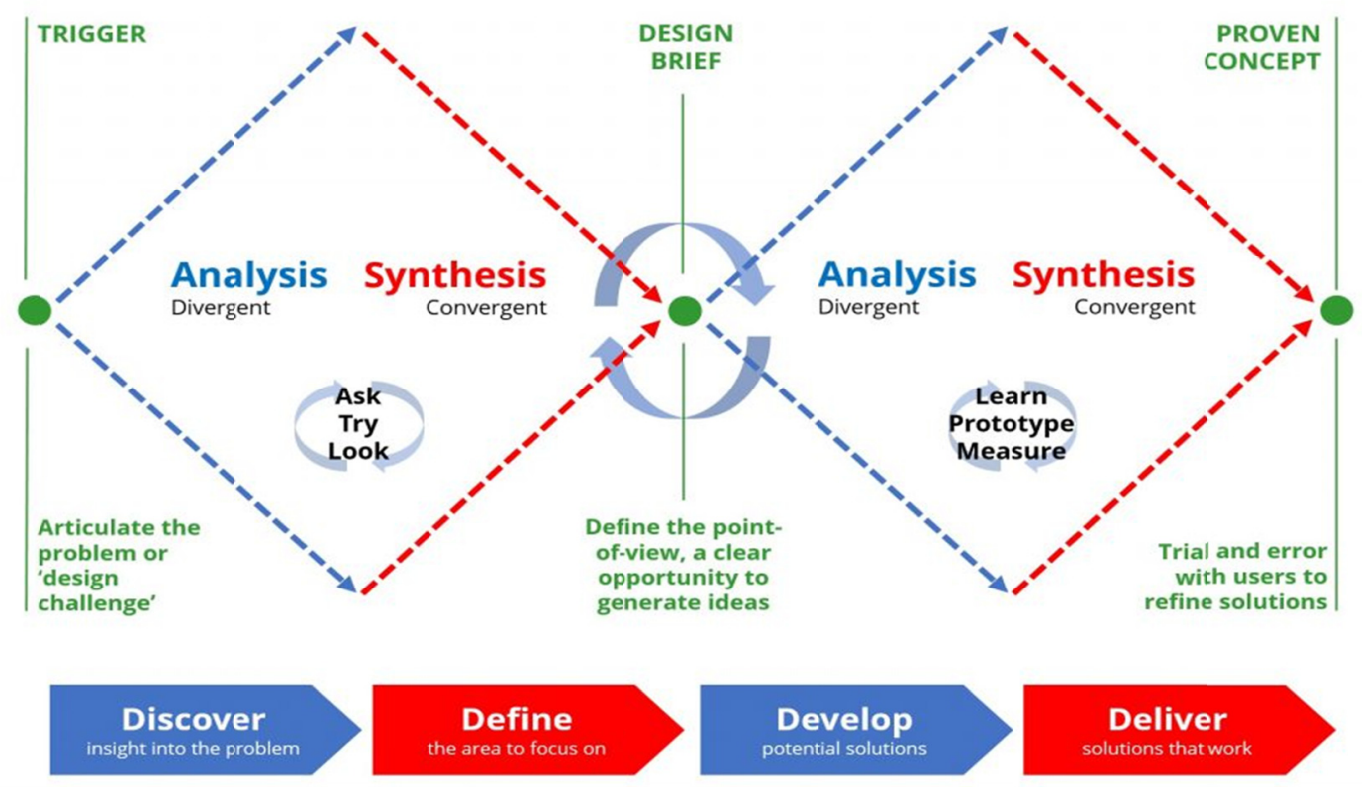

Figure 2. Double-diamond design process of design thinking

Source: $\underline{\text { www.andyeklund.com/how-design-thinking-works/ }}$

\subsection{Packaging Design}

The American Packaging Association defined packaging as "a coordinated system of preparation of goods for shipment, distribution, storage and merchandising at optimum costs compatible with the requirements of the product" (Long, 1994). Packaging design involves functionality, visual design, and brand marketing problems; such problems range from protecting the content of the package to effectively presenting the brand image (Orth \& Malkewitz, 2008). The original function of packaging is to protect products; however, with the increase in consumer awareness and onset consumer social structure over time, packaging is expected to increase sales in addition to the original function of protecting products. Packaging design generally entails planning overall packaging problems, and it includes selecting packaging methods and materials, applying visual design thinking (surface pattern design) (Limon, Kahle, \& Orth, 2009), and conveying and increasing the value of product messages (Yen \& Lin, 2010). In summary, packaging not only serves the function of protecting products but also has implicit marketing functions; this is because the packaging design quality can affect consumers' evaluation and purchase intention (Schoormans \& Robben, 1997).

In general, packaging design can be divided into two categories according to the intended purpose: commercial packaging design (or consumption) and industrial packaging design (structural packaging design; Wang, 1996). Any packaging design should have six main functions, which are listed as follows: (1) preserve the product until it reaches the consumer; (2) minimize waste and damage during product distribution and storage; (3) ensure product cleanliness and security during delivery; (4) facilitate product handling, stacking, storage, and transportation; (5) facilitate product differentiation from other products in a store; and (6) provide product information and consumption instructions to consumers (Calver, 2004; Ho, 2008). Packaging affects people's everyday lives: it not only protects, stores, and enhances products but also enables people to enjoy their lifestyles (Limon et al., 2009). Therefore, packaging affects people's lives, and people's lifestyles also affects packaging (Ho, 2008). To meet the demand for design talents in the 21st century, countries worldwide are implementing different levels of reforms and explorations. This is because the cultivation of design talents involves socioeconomic, political, and cultural aspects (Abdallah \& Darwish, 2010). Different methods of cultivating human talents are applied in different eras, and the task of talent cultivation in the 21 st century should not be neglected.

\subsection{Reflection on Taiwan's Packaging Design Teaching}

Packaging design is a required course in most university-level design education programs in Taiwan, thus indicating the importance of this professional course. However, previously, the teaching of arts and that of design 
were integrated. Specifically, teachers previously focused on professional theories, and this type of "dynamic thinking" and "static teaching" is not effective for teaching students to transform design plans into products. The main cause of the aforementioned problem is that teachers' teaching was inconsistent with actual practical scenarios. Additionally, teaching methods were limited because of the enclosed teaching environment. Teaching processes were repressive, passive, negative, and enclosed because teachers were required to adhere to teaching standards and order (Wang, 2016). Ho (2008) provided the following teaching suggestions for addressing this problem: (1) introduce actual products in the course to enable students to experience actual packaging practices independently or in groups; (2) design lessons that can enable students to understand the concepts of packaging on the basis of the design knowledge they have gained; and (3) guide students to enhance their design performance and communication ability to meet industrial standards. Overall, the importance of packaging design is recognized in Taiwan; however, Taiwanese teachers previously emphasized the teaching of theories, making it difficult for students to discover the relationship between product packaging and consumers and identify actual consumer needs. Therefore, creative teaching reforms should be implemented in packaging design courses in Taiwan.

The principle of packaging design is to convey design thinking and teach design methods. The purpose of creating such reforms is not to cultivate designers but to guide students in expressing themselves and cultivating real problem-solving abilities, thereby enabling them to propose creative packaging design concepts. However, the question as to how to achieve creative teaching in packaging design courses requires clarification. Ho (2008) proposed the implementation of three trial policies. (1) Reorganize the processes of packaging design: New generations of packaging designers must understand the culture of their society, entrepreneurship, product content, and consumer groups before implementing new packaging design concepts. Thus, they can make accurate and precise design positioning decisions. (2) Introduce products in the course: In previous design teaching methods, students were taught virtual design topics that had limited connection with industry. This led students to focus on aesthetic designs, which resulted in products that were visually pleasing but had little functionality. (3) Introduce design competitions in teaching: Competitions can enable students to experience a complete design process through completing a design project. Moreover, the competitions can enable students to experience professional standards, enable them to experience the difficulties and satisfaction associated with design processes, and stimulate their desire for knowledge and creative thinking.

\section{Teaching Evidence}

\subsection{Course Design}

A packaging design course is a professional design course that combines material application, design aesthetics, and brand marketing. It is also a comprehensive science course that emphasizes the cultivation of students' creative thinking and practical abilities. Therefore, we developed a course that involved design thinking and innovative teaching plans to guide students in implementing packaging designs. Table 1 presents the related course information and course content.

Table 1. Teaching plans for packaging design

\begin{tabular}{ll}
\hline Course information & Content description \\
Teaching goals & $\begin{array}{l}\text { Cultivate students' ability to think from the perspective of product packaging, brand image, and marketing. } \\
\text { Topics included spatial structure of packaging, product positioning, product marketing, and graphic visual } \\
\text { design. Train students to enhance their structural creativity, visual aesthetics, design thinking ability, and } \\
\text { design problem-solving ability through rational analysis. }\end{array}$ \\
\hline Teaching hours & $\begin{array}{l}\text { The duration of the course was } 7 \text { weeks. The course was taught } 3 \text { hours per week, and the total course time } \\
\text { was } 21 \text { hours. }\end{array}$ \\
\hline Teaching content & $\begin{array}{l}\text { Packaging materials and the form of finished products, packaging design and marketing, visual design } \\
\text { skills for product packaging, packaging design inspirations, and packaging structural design tests. }\end{array}$ \\
\hline (1) $\begin{array}{l}\text { Lecturing (20\%): invite teachers from the design industry to share their packaging design cases and } \\
\text { enable students to discover and understand the process of packaging design and gain inspiration } \\
\text { from practical cases. }\end{array}$ \\
(2) In-class practical (40\%): instruct groups and teams to develop ideas and improve the packaging \\
design of actual products; students learn problem-solving methods from practical exercises. \\
Group discussion (40\%): instruct students to analyze product brand characteristics, consumer \\
groups, product features, assortment structures, existing packaging design problems, and other items, \\
and finally, encourage them to propose innovative designs on the basis of the analysis of these \\
problems.
\end{tabular}




(1) Empathy: guide students to understand consumers and product design problems through observation
of actual products in shops
(2) Define: guide students to consider the relationship between product packaging and its specific user
groups and redefine and clarify consumer needs.
(3) Ideate: instruct group members to brainstorm together and share problem-solving methods and
innovative ideas within the groups.
(4) Production of prototype: instruct students to select use a specific consumer, and develop a story for
the consumer together, and then develop product prototypes that are easy to produce.
(5) Test: apply situation interpretation and then test the feasibility of product prototypes and determine
areas that can be improved in the future.

\subsection{Teaching Practice}

According to the argument of the d.school, the purpose of teaching design thinking is to cultivate innovation in students. To achieve this goal, the d.school invited several experts and scholars in various fields to form a teaching team providing domain-related techniques and knowledge (Rauth et al., 2010). Accordingly, during the progress of this course, experts in advertising and marketing, brand design, and graphic design were invited to form a design thinking teaching team. The team could help students to discover packaging design problems and produce innovative ideas. Moreover, this course was based on the double-diamond design process of the d.school and can be used to train students to propose innovative packaging designs by answering "what," "who," "why," and "how" questions (Figure 3). The main teaching points are detailed as follows:

1) Human-centered approach: From the perspective of market segmentation and through the actual shopping process of consumers, students should observe packaging problems consumers face when they purchase food. Accordingly, the students should attempt to propose innovative solutions.

2) Empathy map: Students should target one consumer in a consumer group and attempt to deduce the consumer's emotions and thoughts when shopping for and using the product. Group members should understand this consumer's position and feelings, and they should consider potential problems from the consumer's perspective and proposed solutions accordingly.

3) Mindfulness of opinion process: When a member is presenting his or her packaging ideas, other members should listen without providing comments or opinions. Other members may expand on the ideas of others, and they can accumulate numerous ideas through group brainstorming think and discussion sessions.

4) Rapid prototyping: By using storyboard, computer graphics, or paperboard models, students should rapidly produce prototypes of product packages to verify the proposed ideas. Design problems can be modified repeatedly to ensure that the new ideas can adequately satisfy consumer needs.

5) Radical collaboration: Each team member should identify his or her position in the team. Members should respect ideas proposed by other members and should be willing to share their own experience and ideas. Criticism should be replaced with acceptance to determine solutions to problems.

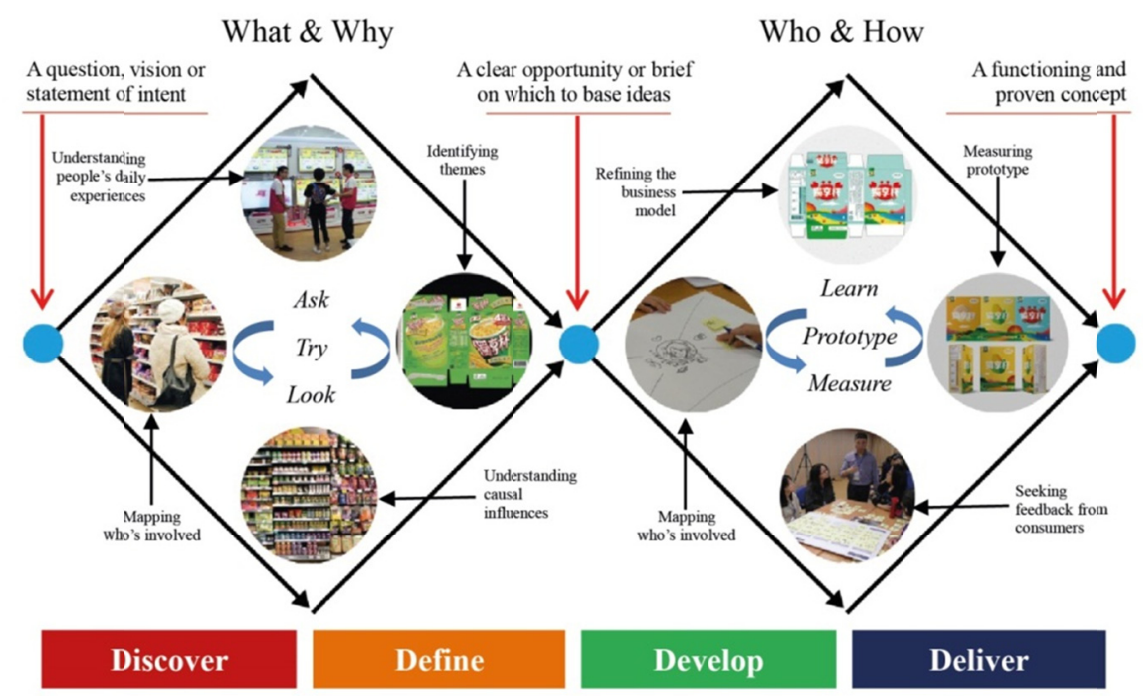

Figure 3. Double-diamond design process in packaging design teaching 


\section{Teaching Outcomes and Discussion}

Packaging design courses have typically been visual communication design courses or among the required courses in commercial design majors. The present study discarded the traditional theory-focused teaching methods and introduced design thinking into a packaging design course. We enabled students to learn through observation, definition, analysis, and implementation and from the perspective of actual product. Specifically, students learned to discover the content of products and identify packaging design problems through learning by doing. This learning method encouraged students to propose new packaging design ideas. Therefore, this course produced rich learning outcomes. The details of the course and problem discussions are provided as follows:

1) Design thinking enhances practical experience: In traditional packaging design courses, theories are presented first before actual practice sessions are introduced. Specifically, students start actual practice after a lecture of design theories. However, because of the existence of a time gap between the introduction of design theories and engagement in practice, students may have forgotten the previously taught theories by the time they start actual practice. Therefore, when designing the teaching plan for this course, teachers referred to the operating procedures of packaging design in a design company. This enabled students to learn by doing. All the practical problems faced by students could help consolidate their knowledge and understanding of packaging design, which could also enhance their interest in learning. Teachers imparted relevant theoretical principles indirectly during their discussion with students about the practical products. This imperceptibly provided the students with a learning process that is based on theory and actual practice (Figure 4).
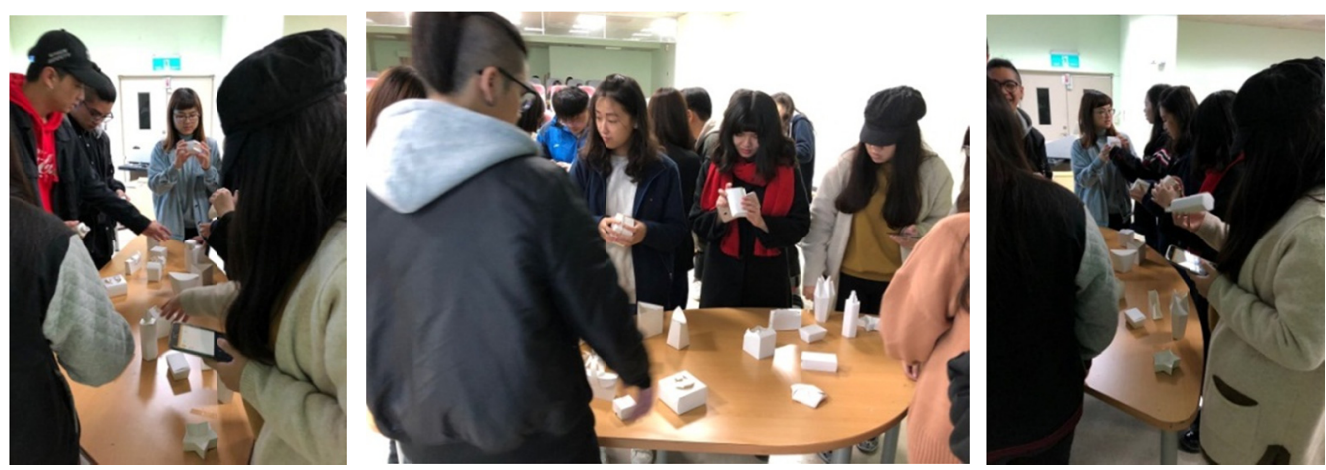

Figure 4. Process of student-teacher discussion about finished products after the completion of actual practice

2) Reorganizing main teaching subjects increases learning motivation: To cultivate design talents, design and art education should emphasize the ability to implement practical design tasks. The course proposed in this study followed industrial operating procedures for managing a design case. This subverted the traditional teacher-based teaching method and engendered a task-driven learning method enabling students to execute design tasks. Thus, students could understand why a task is performed and for whom the task is performed; this also encouraged students to seek knowledge proactively, thereby improving their learning motivation. To achieve objective of task-driven learning, lecturers used the fund of the course and bought numerous products to enable the students in each group to determine the form of the products. By actively analyzing the style, functionality, and materials of the products and considering the relationship between products and structural design, the students could propose innovative structural packaging design ideas (Figure 5). 


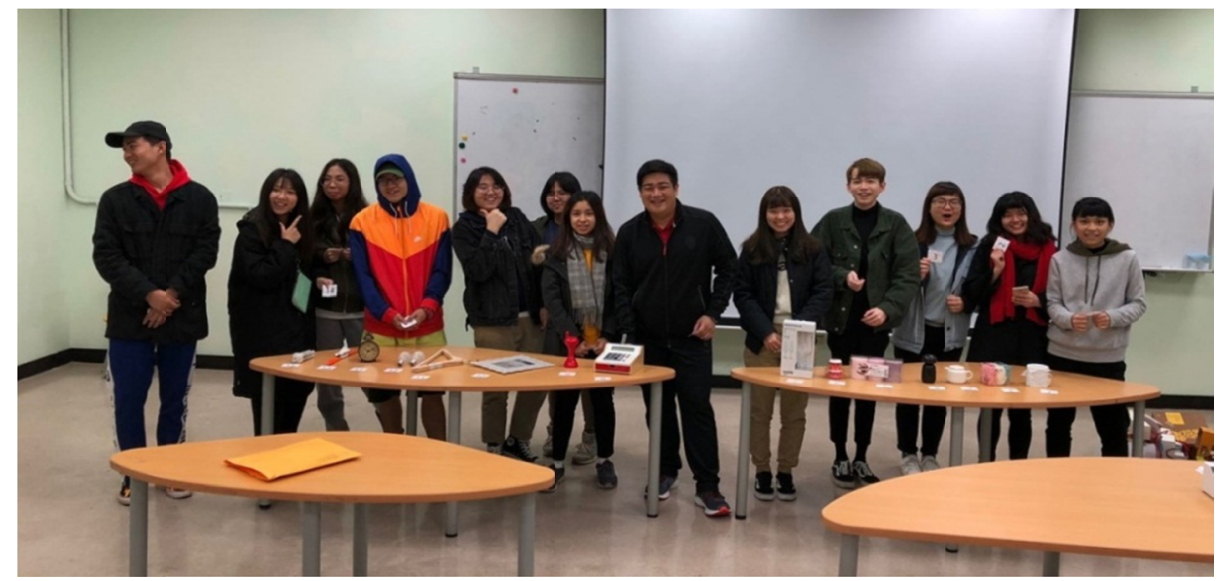

Figure 5. Task-driven learning enables students to determine product form independently

3) Search for self-worth through teamwork: Design requires teamwork. Every designer is independent; however, when entrusted with a design task, designers should avoid personal thinking and should gain inspiration from other team members to solve problems rationally. This is particularly true for tasks that involve not only design problems but also brand marketing, consumer behavior analysis, and wrapper structure. To determine the optimal solution and design form, collaborative thinking in a team is required. Therefore, the course proposed in this study emphasized imparting professional knowledge and techniques and fostering teamwork. This enabled the students to learn by doing and actively search for self-worth in their teams simultaneously. However, as the course progressed, teachers found that students aged 19 to 20 years faced difficulties in identifying their positions in small teams. This may be because all students came from different backgrounds and faced considerable challenges in establishing a balance in the teams and achieving a tolerable task distribution among team members. According to the teachers' observation, smoother teamwork resulted in higher design performance, whereas turbulent teamwork resulted in lower design performance. Therefore, when designing courses for new generations of designers, teachers must consider how to cultivate students' ability to work in a team (Figure 6).
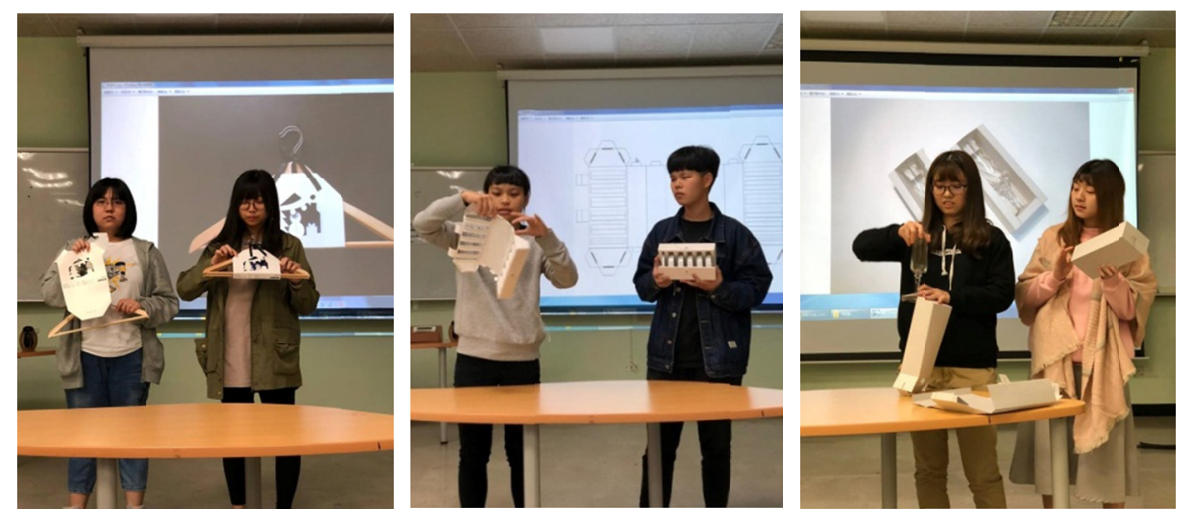

Figure 6. Result presentation of innovative structural packaging design groups

4) Adjusting visual design by considering consumers' perspectives: Packaging designers in the current increasingly complex society must learn how to think from consumers' perspective to adjust their designs. Specifically, designers should adopt the so-called five Ws of design thinking: (1) What is the product? (2) Who is the target consumer? (3) When is the selling time? (4) Where is the location of selling? (5) Why type of visual design may increase value of product packaging? However, packaging design courses do not guide students to think from consumers' perspective. Students may be able to create elegant packaging designs, but the lack of product positioning and the imprecise consideration of who the target consumers are can lead to the production of packaging designs that are inconsistent with consumer needs. Therefore, the course proposed in this study exposed students to actual products, thus preventing egotism among students; that is, 
rather than arbitrarily creating designs, students could review the style of visual design from the perspectives of market segmentation and consider consumer needs, thereby achieving value-added learning of packaging design (Figure 7).
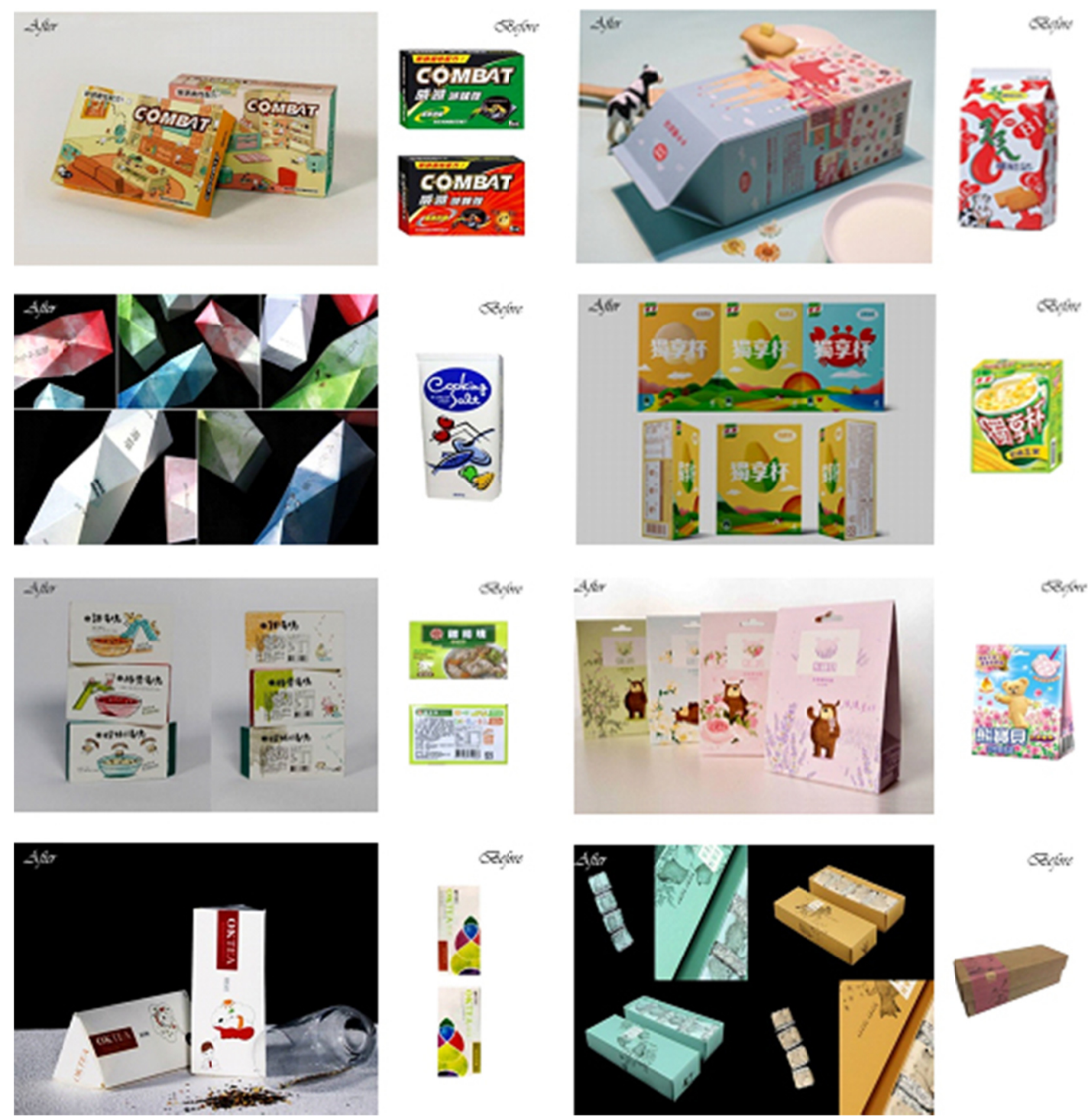

Figure 7. Teaching outcome of changes in product packaging design

\section{Conclusion and Suggestions}

In recent years, technological advancements have expedited the circulation of products and society has become increasingly complex. Currently, packaging design is no longer considered a subsidiary of products. Consumers currently have high expectations for product packaging. Vocational education for cultivating design talents should involve more practical teaching methods that can guide students to discover practical problems and seek appropriate solutions. This can thus provide the foundation for cultivating students' ability to think independently and practically. Moreover, packaging design should be consistent with consumer needs. The unique characteristics of and needs for products should be analyzed by considering consumers' culture, and students should be taught to emphasize consumer needs. Specifically, students should be taught to develop designs that are consistent with the everyday needs of consumers; thus, design talents that suit the market can be cultivated.

From a design education perspective, to achieve innovative packaging design, teachers should discard theory-based lectures and instead adopt teaching methods that enable students to learn by doing first, followed by other lectures. That is, teachers should lead students to discover practical problems and seek solutions first, 
followed by establishing their theoretical basis. This teaching method can effectively improve students' learning interest and motivation. Furthermore, the traditional teaching model is marred by the barrier between students and the teacher. Specifically, teacher speaks continually in front of students, who only listen without the opportunity to respond. This model can be modified by rendering students the main parties and teachers the complementary parties in the learning process. Thus, students can have the opportunity to think about the content they wish to learn and interact with the teachers during learning.

\section{References}

Abdallah, N., \& Darwish, R. (2010). Packaging design course teaching improvement: A case study in the faculty of applied arts, Egypt. Indian Journal of Science and Technology, 3(10), 1108-1112. https://doi.org/10.17485/ijst/2010/v3i10/29841

Brown, T., \& Wyatt, J. (2010). Design thinking for social innovation. Development Outreach, 12(1), 29-43. https://doi.org/10.1596/1020-797X_12_1_29

Calver, G. (2004). What is packaging design?. New York, NY: Rotovision.

Dunne, D., \& Martin, R. (2006). Design thinking and how it will change management education: An interview and discussion. Academy of Management Learning \& Education, 5(4), 512-523. https://doi.org/10.5465/amle.2006.23473212

DuPuis, S., \& Silva, J. (2008). Package design workbook: The art and science of successful packaging. New York, NY: Rockport Publishers.

Ho, W. L. (2008). The theories of current packaging design and their implications for teaching. Visual Arts Forum, 3, 20-38. [Publish in Chinese]

Hsu, H. J. (2002). The evaluation of commercial package design from package form point of view in Taiwan. Journal of National Taiwan College of Arts, 70, 29-42. [Publish in Chinese]

Hsu, H. J., \& Lin, C. D. (2006). The Application on local culture in package design-a case study of package design in tamsui local feature product. Thesis of Plastic Arts Division, December, 91-111. [Publish in Chinese]

Johansson-Sköldberg, U., Woodilla, J., \& Çetinkaya, M. (2013). Design thinking: past, present and possible futures. Creativity and Innovation Management, 22(2), 121-146. https://doi.org/10.1111/caim.12023

Limon, Y., Kahle, L. R., \& Orth, U. R. (2009). Package design as a communications vehicle in cross-cultural values shopping. Journal of International Marketing, 17(1), 30-57. https://doi.org/10.1509/jimk.17.1.30

Lindberg, T., Meinel, C., \& Wagner, R. (2011). Design thinking: A fruitful concept for it development?. In: Design Thinking, Berlin: Springer, 3-18. https://doi.org/10.1007/978-3-642-13757-0_1

Lon, D. Y. (1996). Commercial package design. Taiwan, Taipei: Ning Meng Huang publisher. [Publish in Chinese]

Lugmayr, A. (2011, September). Applying design thinking as a method for teaching in media education. In: Proceedings of the 15th International Academic MindTrek Conference: Envisioning Future Media Environments, ACM, 332-334. https://doi.org/10.1145/2181037.2181100

Lugmayr, A., Stockleben, B., Zou, Y., Anzenhofer, S., \& Jalonen, M. (2014). Applying "Design Thinking” in the context of media management education. Multimedia Tools and Applications, 71(1), 119-157. https://doi.org/10.1007/s11042-013-1361-8

Melles, G., Howard, Z., \& Thompson-Whiteside, S. (2012). Teaching design thinking: Expanding horizons in design education. Procedia-Social and Behavioral Sciences, 31, 162-166. https://doi.org/10.1016/j.sbspro.2011.12.035

Orth, U. R., \& Malkewitz, K. (2008). Holistic package design and consumer brand impressions. Journal of Marketing, 72(3), 64-81. https://doi.org/10.1509/jmkg.72.3.64

Rauth, I., Köppen, E., Jobst, B., \& Meinel, C. (2010). Design thinking: An educational model towards creative confidence. In DS 66-2: Proceedings of the 1st International Conference on Design Creativity (ICDC 2010).

Razzouk, R., \& Shute, V. (2012). What is design thinking and why is it important?. Review of Educational Research, 82(3), 330-348. https://doi.org/10.3102/0034654312457429

Rettie, R., \& Brewer, C. (2000). The verbal and visual components of package design. Journal of Product \& 
Brand Management, 9(1), 56-70. https://doi.org/10.1108/10610420010316339

Rundh, B. (2009). Packaging design: creating competitive advantage with product packaging. British Food Journal, 111(9), 988-1002. https://doi.org/10.1108/00070700910992880

Scheer, A., Noweski, C., \& Meinel, C. (2012). Transforming constructivist learning into action: Design thinking in education. Design and Technology Education: An International Journal, 17(3), 8-19.

Schoormans, J. P. L., \& Robben, H. S. J. (1997). The effect of new package design on product attention, categorization and evaluation. Journal of Economic Psychology, 18(2-3), 271-287. https://doi.org/10.1016/S0167-4870(97)00008-1

Serafin, R. (1985). Packaging becomes an art. Advertising Age, 12, August, 66.

Tschimmel, K. (2012). Design thinking as an effective toolkit for innovation. In: ISPIM Conference Proceedings of the International Society for Professional Innovation Management (ISPIM). https://doi.org/10.13140/2.1.2570.3361

Wang, B. N. (1996). Commercial package design. Taiwan, Taipei: Yi Fong Tang publisher. [Publish in Chinese]

Wang, J. (2016). Discussion on the reform of packaging design training course in higher vocational colleges. Journal of Shandong Institute of Commerce and Technology, 1, 33-37. [Publish in Chinese]

Webb-Jenkins, J. (2001). The threat to our future. Environmental Engineering, 14(1), 56.

Yen, J., \& Lin, S. Y. (2010). A Study of the variables of packaging design that affect brand equity. Journal of Design, 15(1), 71-91. [Publish in Chinese]

\section{Copyrights}

Copyright for this article is retained by the author(s), with first publication rights granted to the journal.

This is an open-access article distributed under the terms and conditions of the Creative Commons Attribution license (http://creativecommons.org/licenses/by/4.0/). 